\title{
Mark and recapture studies of two reef sparids in the Tsitsikamma Coastal National Park
}

\author{
C.D. BUXTON and J.C. ALLEN
}

Buxton, C.D. and J.C. Allen. 1989. Mark and recapture studies of two reef sparids in the Tsitsikamma Coastal National Park. - Koedoe 32 (1): 39-45. ISSN 0075-6458.

\begin{abstract}
A mark and recapture study of two reef sparids, Chrysoblephus laticeps and C. cristiceps, was done in the Tsitsikamma Coastal National Park. Fish were marked with plastic anchor tags and an intraperitoneal injection of oxytetracycline. All recaptures were taken within two kilometres of the tagging locality, suggesting that both species are resident in the area. Growth in length during the period at liberty was very variable and sometimes negative, but was comparable with published growth rates.
\end{abstract}

C.D. Buxton, Department of Ichthyology and Fisheries Science, Rhodes University, P.O. Box 94, Grahamstown, 6140 Republic of South Africa (Formerly: Port Elizabeth Museum, P.O. Box 13147, Humewood, 6013); J.C. Allen, Tsitsikamma Coastal National Park, Storms River, 6308 Republic of South Africa.

\section{Introduction}

During 1985-86 an intensive tagging programme was carried out in the Tsitsikamma area with a two-fold objective. The first was to study the movements of Roman Chrysoblephus laticeps (Cuvier, 1829) and dageraad C. cristiceps (Cuvier in C. \& V., 1830) so that the degree of residency in these species could be established. This information is necessary to evaluate the usefulness of marine reserves in protecting exploited linefish species. The second was to validate age and growth studies by marking fish with oxytetracycline. When taken up in hard tissues e.g. otoliths, this chemical provides a mark from which subsequent growth over a known time period can be estimated (Wild \& Foreman 1980).

No attempt was made to estimate population density by the mark-recapture method (Seber 1973; Laird \& Stott 1978), because the necessary assumption of equal catchability is unrealistic when sampling fishes with lines. Other assumptions such as closed populations and unrestricted individual mobility may also be unrealistic for reef fishes (Thresher \& Gunn 1986). 


\section{Methods}

Techniques available to mark fishes are numerous and ideally the choice of a particular method should only be made after experimental trials (Laird \& Stott 1978). Time constraints prevented a systematic testing of the various techniques available as well as a study of tag retention. Short experimental trials were run to test the most suitable tag location on the fish, and the suitability of different length tags. Anchor tags (FD67C Floy Tag Manufacturing Co. Seattle, Washington) were chosen because individual identification was necessary. The tags were easily identified upon recapture and other workers had found them to be suitable for a wide range of reef species (Stander \& Nepgen 1968; Shaw, Nagtegaal, Archibald \& Leaman 1981; Davis \& Reid 1982).

Tagging took place in the Tsitsikamma Coastal National Park, a marine sanctuary extending $5 \mathrm{~km}$ offshore and covering a $60 \mathrm{~km}$ stretch of coast between Nature's Valley (34'59'S, $\left.23^{\circ} 34^{\prime} \mathrm{E}\right)$ and Oubos-strand $\left(34^{\circ} 04^{\prime} \mathrm{S}, 24^{\circ} 12^{\prime} \mathrm{E}\right)$. Specimens were caught from a small boat using handlines with $4 / 0$ barbless hooks. Immediately on capture the fish was placed on a foam rubber mat to minimise injury and the fork length measured to the nearest millimetre. The swimbladder was deflated using a hypodermic needle and a single tag injected below the second dorsal spine, taking care to anchor the tag in the pterygiophores. The fish were given an intraperitoneal injection of oxytetracycline (OTC), called Terramycin, at a dosage of approximately $50 \mathrm{mg} / \mathrm{kg}$ body weight (Shaw et al. 1981) and returned to the water at the site of capture. The calcium specific antibiotic OTC incorporated in the growing periphery of the otolith (Wild \& Foreman 1980) shows up as a mark under ultra-violet illumination (Casselman 1974). The tagging operation took less than a minute to complete and most fish swam away vigorously when released.

Tags carried an identification number, the Port Elizabeth Museum address and the word 'Reward'. Notices advertising the project were widely distributed in the area between Mossel Bay and East London and in the local press (Fig. 1). A reward was offered for the return of whole tagged fish. For each recapture the date, place of capture and fork length were recorded and if possible the whole fish or the head was obtained for the extraction of otoliths (See Fig. 1).

\section{Results}

\section{(i) Preliminary study}

Thirteen Chrysoblephus laticeps and 13 C. cristiceps were tagged and kept in a $16 \mathrm{~m}$ diameter circular aquarium for 1-5 months. Seven of the $C$. cristiceps were tagged with short tags $( \pm 20 \mathrm{~mm})$ and six with tags between $50-100$ millimetres. The shorter tags were observed to spin and cause severe lesions around the tag site after a few days. All of the other fish, including those recaptured from the sea, showed no signs of discomfort from the longer tags. Three of the $C$. laticeps were tagged in the operculum. This appeared to cause some irritation to the fish as they were observed to repeatedly brush the substratum in an obvious attempt to dislodge the tag and all of these tags fell off after less than two weeks. This method was thus discontinued.

(ii) Main study

A total of 379 C. laticeps and 85 C. cristiceps were tagged from June 1985 to May 1986 in the area between the Knoll and Rheeders. Because of the size-selective sampling method only adult fish were tagged, the length frequencies of which are shown in Figure 2. Tagged $C$. laticeps ranged in 


\section{REWARD-BELONING}

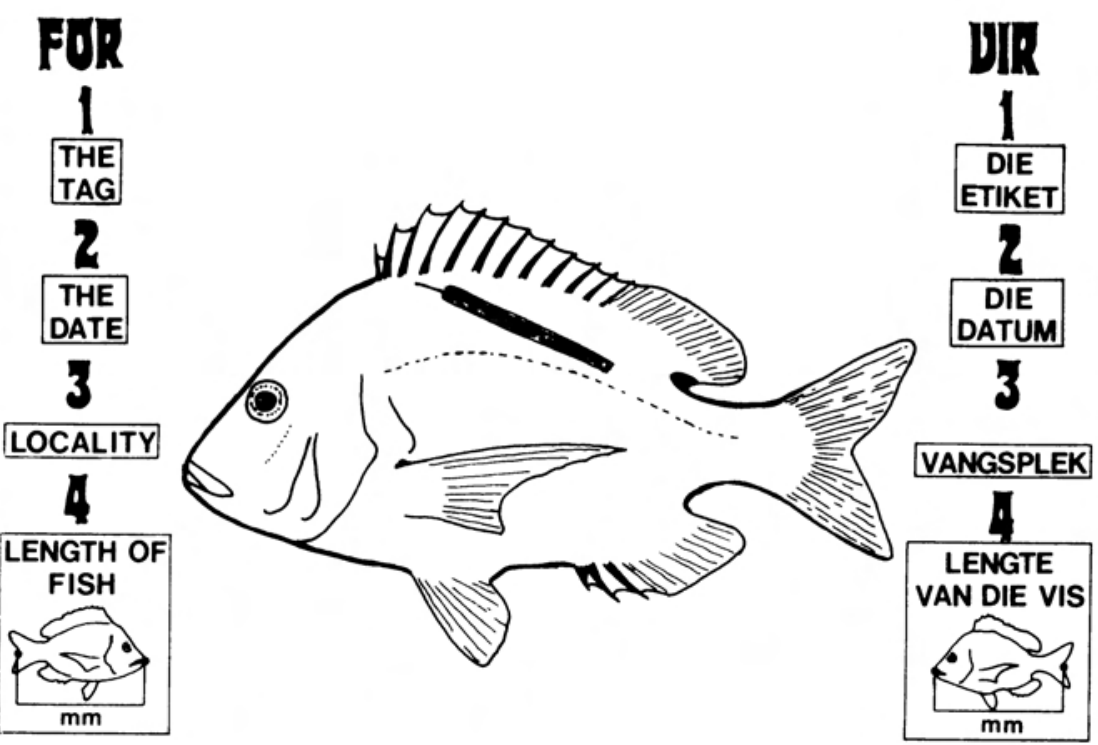

STUUR AAN : SEND TO:

PORT ELIZABETH MUSEUM

P. O. BOX 1314 7, HUMEWOOD, 6013. TEL. 29144 OR TSITSIKAMMA COASTAL NATIONAL PARK

INFORMATION OFFICE, P.O. STORMSRIVIER. TEL.(04237)-652
R5.00 PAID FOR EACH TAG RETURNED

WILL BE DOUBLED IF ACCOMPANIED BY THE WHOLE FISH
R5.00 WORD VIR ELKE ETIKET BE TAAL

DIÉ SAL VERDUBBEL AS DIE HELE VIS

SAAMGESTUUR WORD

Fig. 1. Notice used to bring the tagging project to the attention of anglers between Mossel Bay and Port Elizabeth. 


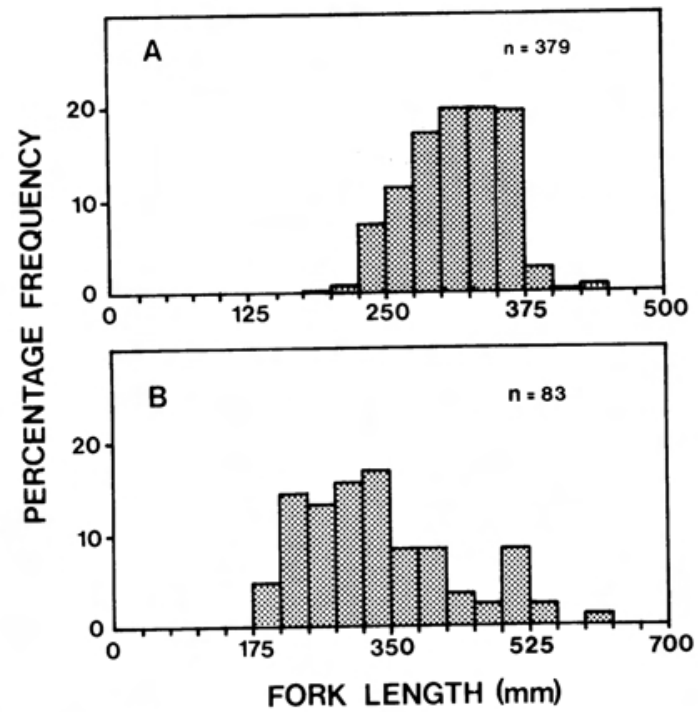

Fig. 2. Length frequencies of all Chrysoblephus laticeps (A) and C. cristiceps (B) tagged in the Tsitsikamma area.

Table 1

Summary of pre- and post-tagging mortalities of Chrysoblephus laticeps and C. cristiceps in the Tsitsikamma Coastal National Park

\begin{tabular}{|lccc|}
\hline \multicolumn{1}{|c}{ Species } & No. & \multicolumn{2}{c|}{ Tagging Mortalities } \\
& Tagged & Pre & Post \\
\hline C. laticeps & 379 & 95 & 8 \\
C. cristiceps & 85 & 37 & 4 \\
\hline
\end{tabular}

Table 2

Recaptures of Chrysoblephus laticeps and C. cristiceps in the Tsitsikamma Coastal National Park

\begin{tabular}{|c|c|c|c|c|c|c|c|c|}
\hline \multirow{2}{*}{ Species } & \multicolumn{3}{|c|}{ Tagged } & \multicolumn{3}{|c|}{ Recapture } & \multirow{2}{*}{$\begin{array}{l}\text { Days at } \\
\text { Liberty }\end{array}$} & \multirow{2}{*}{$\begin{array}{l}\text { Length } \\
\text { Increase } \\
(\mathrm{mm})\end{array}$} \\
\hline & Date & Area & FL & Date & Area & FL & & \\
\hline C. laticeps & 850618 & $\mathrm{Rh}$ & 362 & 850624 & Sk & ? & 6 & ? \\
\hline$"$ & 850620 & $\mathrm{Rh}$ & 292 & 850629 & Sk & $?$ & 9 & $?$ \\
\hline$"$ & 850620 & $\mathrm{Rh}$ & 307 & 850816 & $\mathrm{Rh}$ & 315 & 57 & 8 \\
\hline$"$ & 850621 & $\mathrm{Rh}$ & 315 & 850718 & $\mathrm{Rh}$ & 312 & 27 & -3 \\
\hline$"$ & 850621 & $\mathrm{Rh}$ & 346 & 850718 & $\mathrm{Rh}$ & 348 & 27 & 2 \\
\hline$"$ & 850621 & $\mathrm{Rh}$ & 296 & 850718 & $\mathrm{Rh}$ & 299 & 27 & 3 \\
\hline$"$ & 850621 & Sk & 312 & 850624 & Sk & $?$ & 3 & $?$ \\
\hline$"$ & 850621 & Sk & 371 & 870107 & Sk & 396 & 565 & 25 \\
\hline$"$ & 850718 & Sk & 349 & 850821 & Sk & 350 & 34 & 1 \\
\hline$"$ & 850821 & Sk & 364 & 860423 & $\mathrm{Kn}$ & 370 & 245 & 6 \\
\hline$"$ & 850825 & $\mathrm{Kn}$ & 305 & 870409 & Sk & 332 & 588 & 27 \\
\hline C. cristiceps & 850618 & $\mathrm{Rh}$ & 360 & 860311 & $\mathrm{Rh}$ & 357 & 265 & -3 \\
\hline
\end{tabular}


length between $181 \mathrm{~mm}$ and $436 \mathrm{~mm}$ and $C$. cristiceps between $212 \mathrm{~mm}$ and 608 millimetres.

Tagging mortalities are summarised in Table 1. Pre-tagging mortality was the most significant contributor to total mortality $(92 \%)$ and resulted from either severe barotrauma, where the gut protruded from the cloaca or the mouth, or from a swallowed hook that could not be removed without injury to the fish. Post-tagging mortality occurred infrequently $(8 \%)$ and was defined as the inability to return a tagged fish to the sea. These fish either floated on the surface or sank without observable movement. Although listed as dead the latter may have recovered. Fish in these two categories were not included in the totals of successfully tagged animals.

Recaptures are summarised in Table 2. Eleven $C$. laticeps were recaptured, three by anglers and eight during tagging operations. Maximum time at liberty was 588 days. All were caught within $2 \mathrm{~km}$ of the tag locality and six of the fish were recaptured on the same reef as they were tagged (Fig. 3 ). Only one $C$. cristiceps was recaptured after 265 days at liberty, also on the same reef as it was tagged. (See Fig.3).

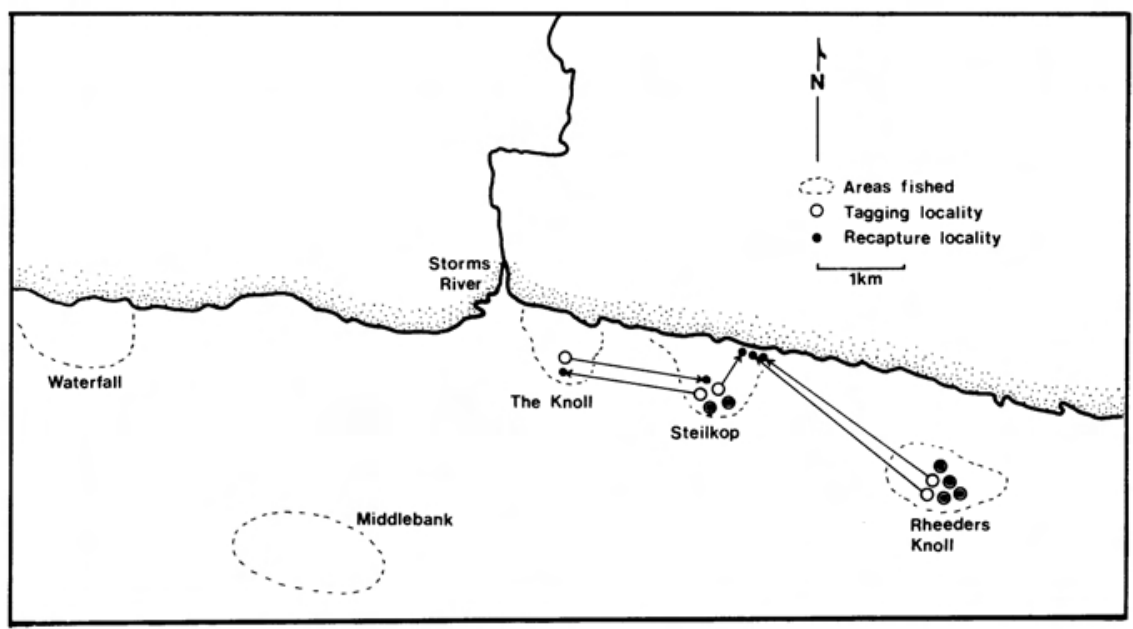

Fig. 3. Map of the tagging and recapture localities of Chrysoblephus laticeps in the Tsitsikamma Coastal National Park.

\section{Discussion}

The increment in lengths of recaptured fish were generally small or negative due to a short time at liberty. Negative growth measured in two of the recaptured fish was disturbing but may have been caused in two ways. Firstly, inaccuracies may result during measuring or recording of the fish length during tagging operations. Secondly, and perhaps more likely, inaccuracies may result through changes in the length of the fish after death. These changes, a result of rigor mortis and later relaxation of the musculature can result in consistent, measurable differences in length after death 
(Ricker 1975; A. Penney, Sea Fisheries Research Institute, Cape Town, pers. comm.). Two C. laticeps, of $305 \mathrm{~mm}$ and $371 \mathrm{~mm}$ at tagging, had grown $27 \mathrm{~mm}$ and $25 \mathrm{~mm}$ respectively during 18 months at liberty. A third fish, of $364 \mathrm{~mm}$ at tagging, had grown $6 \mathrm{~mm}$ during eight months at liberty. The predicted growth rates for these fish, based on an age determination using sectioned otoliths, were $23,5 \mathrm{~mm}, 9 \mathrm{~mm}$ and $5 \mathrm{~mm}$ respectively (Buxton 1987). The similarity between observed and predicted growth in C. laticeps was good even though the sample size was small, and agrees with the slow growth rate determined by otolith analysis (Buxton 1987). Although the single recaptured $C$. cristiceps had been at liberty for over eight months, growth rate during this time was negative.

Unfortunately the otoliths of the fish that had been at liberty the longest were not obtained for age validation. It is hoped, however, that future samples will yield positive results from fish marked with oxytetracycline.

A significant aspect of the study was that all recaptures were made very close to the area of tagging and no recaptures were reported from outside the park. The results are similar to those of Stander \& Nepgen (1968) and Nepgen (1977) who tagged a number of reef sparids including $C$. laticeps in the False Bay area, and found that most recoveries were from the area of tagging. A high degree of residency has also been reported in studies of sparids elsewhere. In the New Zealand snapper, Chrysophrys auratus, movements were restricted to a radius of less than $10 \mathrm{~km}$ (Paul 1967; Tong 1978; Crossland 1982), and in a study of the movements of red porgy Pagrus pagrus, a species common on both sides of the Atlantic, Grimes, Manooch \& Huntsman (1982) found a high degree of residency.

These observations suggest that many sparids are sedentary, and do not normally migrate over large distances. However, before accepting this conclusion for $C$. laticeps and $C$. cristiceps, several limitations must be considered. Firstly, research fishing effort in the park was limited to the area between Waterfall and Rheeders and, consequently, movements of fish outside this area but still within the park would go undetected. Secondly, recaptures from areas outside the park would necessarily come from anglers, who are often suspicious of research activities (Randall 1961) and may resist reporting recaptures in spite of the reward offered. Thirdly, the percentage recaptures was low, 2,9 \% for $C$. laticeps and 1,2\% for $C$. cristiceps, indicative of a low number of fish tagged. With a small sample the chance of catching fish outside the park would be small because the probability of recapture decreases proportionately with distance from the tagging locality (Robson \& Reiger 1964).

Nevertheless, the recapture of most of the fish from the same reef as the one on which they were tagged, even after as long as 18 months at liberty, suggests that $C$. laticeps and $C$. cristiceps are sedentary species with resident populations in the park. This information is crucial to the understanding of the use of marine reserves as a management option for certain reef fish species because it implies that adult populations are being protected by the marine reserve. These populations would presumably be capable of seeding adjacent areas through larval drift. However, little is known about the early life history stages of these and other reef fishes, and this research is needed to fully understand the implications of this study. 


\section{Acknowledgements}

We would like to thank J.R. Clarke for his assistance with the data collection and comments on the manuscript as well as an anonymous referee for improvements to an earlier draft. This research was funded by the South African Committee for Oceanographic Research as well as the National Parks Board of Trustees.

\section{References}

BUXTON, C.D. 1987. Life history changes of two reef fish species in exploited and unexploited marine environments in South Africa. Ph.D. thesis. Rhodes University, Grahamstown.

CASSELMAN, J.M. 1974. Analysis of hard tissue of pike Esox lucius L. with special reference to age and growth. Pp. 13-27. In: BAGENAL, T.B. (ed.). Ageing of Fish. England: Unwin Brothers.

CROSSLAND, J. 1982. Movements of tagged snapper in the Hauraki Gulf. N. Z. Fish. Res. Div. Occ. Publ. 35: 1-15.

DAVIS, T.L.O. and D.D. REID. 1982. Estimates of tag shedding rates for Floy FT-2 Dart and FD-67 Anchor tags in Barramundi, Lates calcarifer (Bloch). Aust. J. Mar. Freshwat. Res. 33: 1113-1117.

GRIMES, C.B., C.S. MANOOCH and G.R. HUNTSMAN. 1982. Reef and rock outcropping fishes of the outer continental shelf of North Carolina and South Carolina, and ecological notes on the red porgy and vermillion snapper. Bull. Mar. Sci. 32: 277-289.

LAIRD, L.M. and B. STOTT. 1978. Marking and Tagging. Pp. 84-100. In: BAGENAL, T. (ed.). IBP Handbook No. 3. Oxford: Blackwell Scientific Publications.

NEPGEN, C.S. DE V. 1977. The biology of the hottentot Pachymetopon blochii (Val.) and the silverfish Argyrozona argyrozona (Val.) along the Cape south west coast. Sea Fish. Branch Inv. Rep. No. 105: 1-35.

PAUL, L.J. 1967. An evaluation of tagging experiments of the New Zealand snapper, Chrysophrys auratus (Forster), during the period 1952 and 1963. N. Z. J. Mar. Freshwat. Res. 1: 455-463.

RANDALL, J.E. 1961. Tagging reef fishes in the Virgin Islands. Proc. Gulf Caribb. Fish Inst. 14: 201-241.

RICKER, W.E. 1975. Computation and interpretation of biological statistics of fish populations. Bull. Fish. Res. Bd Can. 191: 1-382.

ROBSON, D.S. and H.A. REIGER. 1964. Sample size in Petersen mark-recapture experiments. Trans. Am. Fish. Soc. 93: 215-226.

SEBER, G.A. 1973. The estimation of animal abundance and related parameters. London: Griffin.

SHAW, W., D.A. NAGTEGAAL, C.P. ARCHIBALD and B.M. LEAMAN. 1981. Rockfish tagging cruises off Southwest Vancouver Island (M/V Ocean King) and off Northwest Vancouver Island and in Queen Charlotte Sound (M/V Blue Waters) during 1980. Can. Data Rep. Fish. Aquat. Sci. 288: 1-133.

STANDER, G.H. and C.S. NEPGEN. 1968. Some facts about linefish - with special reference to False Bay. S. Afr. Shipp. News fish. Ind. Rev. 23: 108-111.

THRESHER, R.E. and J.S. GUNN. 1986. Comparative analysis of visual census techniques for highly mobile, reef-associated piscivores (Carangidae). Env. Biol. Fish. 17: 93-116.

TONG, L.J. 1978. Tagging snapper Chrysophrys auratus by scuba divers. N. Z. J. Mar. freshwat. Res. 12: 73-76.

WILD, A. and T.J. FOREMAN. 1980. The relationship between otolith increments and time for yellowfin and skipjack tuna marked with tetracycline. Bull. inter-Am. Trop. Tuna Commn 17: 509-560. 